\title{
METODE PENALARAN SISTEM PAKAR MENGGUNAKAN MODEL HIBRID FUZZY DEMPSTER SHAFER UNTUK IDENTIFIKASI HAMA DAN PENYAKIT TANAMAN JAGUNG
}

\author{
Nurmahaludin(1), Gunawan Rudi Cahyono(1) \\ mahaludin@poliban.ac.id(1), m4sgunnana@gmail.com ${ }^{(2)}$
}

(1) Staf Pengajar Jurusan Teknik Elektro Politeknik Negeri Banjarmasin

\begin{abstract}
Ringkasan
Dempster Shafer merupakan metode yang banyak digunakan dalam penalaran sistem pakar. Penarikan kesimpulan atas suatu permasalahan dalam metode tersebut didasarkan pada penggabungan dua buah evidence (fakta) yang ada, dimana masing-masing fakta mempunyai ukuran kepercayaan yang dinyatakan dalam nilai densitas $m 1$ dan $m 2$.

Penelitian ini akan menentukan nilai densitas $(m)$ dengan menggunakan logika fuzzy. Input fuzzy adalah tingkat kemunculan gejala dan tingkat keunikan gejala, sedangkan output fuzzy adalah nilai crisp dari probabilitas densitas. Derajat kepastian dari jawaban pakar berdasarkan gejala yang diberikan kemudian dihitung menggunakan aturan kombinasi Dempster. Implementasi dalam penelitian ini adalah sistem pakar untuk identifikasi hama dan penyakit tanaman jagung. Aplikasi ini dipilih agar masyarakat tani mampu memanfaatkan sistem pakar tersebut dalam rangka memberikan pengetahuan kepakaran mengenai hama penyakit dan cara pemberantasannya.

Sistem pakar yang dirancang dapat memberikan hasil identifikasi berdasar pada gejala yang diinputkan. Penentuan jenis hama atau penyakit yang menyerang didasarkan pada proses pencarian nilai kepercayaan terhadap suatu diagnosa. Semakin besar nilai kepercayaan semakin besar pula potensi hama/penyakit yang menyerang, begitu pula sebaliknyaPenelitian ini bertujuan untuk mengetahui pengaruh beda media pendingin pada proses hardening pada kekerasan pegas daun. Proses penelitian adalah dengan jalan memanasan pegas daun sampai suhu didaerah atau diatas daerah kritis disusul dengan pendinginan yang cepat. Bila kadar karbon diketahui, suhu pemanasannya dapat dibaca dari diagram fasa besi-carbida. Akan tetapi bila komposisi baja tidak diketahui, perlu diadakan percobaan untuk mengetahui daerah pemanasannya. Cara yang terbaik ialah memanaskan dan mencelup beberapa potongan baja pada suhu tertentu disusul dengan pengujian kekerasan. Bila suhu yang tepat telah diperoleh akan terjadi perubahan dalam kekerasan dan sifat lainnya.
\end{abstract}

Kata Kunci: Sistem Pakar, Dempster-Shafer, Hama Tanaman Jagung

\section{PENDAHULUAN}

Sistem pakar adalah sistem yang berusaha mengapdosi pengetahuan dari pakar ke komputer, agar komputer dapat menyelesaikan masalah seperti yang biasa dilakukan oleh para ahli. Sistem pakar terbukti sangat membantu karena masyarakat menjadi mempunyai kemampuan untuk menyelesaikan suatu permasalahan. Sebagai contoh, petani dapat mengidentifikasi hama dan penyakit yang menyerang tanamannya tanpa harus menunggu kedatangan penyuluh pertanian sehingga antisipasi/pemberantasan dapat dilakukan sedini mungkin.

Akan tetapi seringkali seorang pakar mengalami keragu-raguan atau tidak yakinan dalam pengambilan kesimpulan, sehingga jawaban yang diberikan menggunakan ukuran derajat keyakinan atau persentase tingkat kepercayaan. Metode penalaran yang tepat untuk mengatasi hal tersebut adalah penalaran dengan ketidakpastian (uncertainty). Metode ketidakpastian yang banyak digunakan dalam sistem pakar adalah Dempster-Shafer. Metode Dempster-Shafer menggunakan nilai densitas $\mathrm{m} 1$ dan $\mathrm{m} 2$ untuk menyatakan derajat keyakinan terhadap evidence 1 dan evidence 2.

Penarikan kesimpulan didasarkan pada perhitungan nilai densitas baru (m3) yang merupakan penggabungan dari kedua densitas tersebut menggunakan rumus kombinasi Dempster. 
Dari uraian di atas dapat dipahami bahwa penentuan nilai probabilitas fungsi densitas (m) menjadi sangat penting karena menentukan tingkat kepastian dari jawaban pakar terhadap suatu permasalahan. Logika fuzzy digunakan untuk memetakan kriteria kualitatif yang menjadi permasalahan dalam penentuan probabilitas nilai densitas $\mathrm{m}$ menjadi nilai-nilai numerik yang bersifat tegas (crisp). Nilai crisp $\mathrm{m} 1 \mathrm{dan} \mathrm{m} 2$ yang diperoleh kemudian digunakan untuk menghitung nilai densitas $\mathrm{m} 3$ yang menyatakan seberapa besar derajat kepastian suatu keputusan pakar terhadap masalah yang ditanyakan.

Model hibrid fuzzy-Dempster-Shafer kemudian digunakan pada proses penalaran sistem pakar. Kepentingan akan adanya metode penalaran yang baik adalah untuk menghasilkan sistem pakar yang handal, yang mampu bertindak layaknya seorang ahli. Aplikasi sistem pakar adalah untuk identifikasi hama dan penyakit tanaman jagung.

\section{KAJIAN PUSTAKA}

Teori Dempster-Shafer merupakan teori matematika yang dikembangkan oleh Arthur P. Dempster dan Glenn Shafer. Teori tersebut memberikan sebuah cara untuk menggabungkan sejumlah evidence kemudian menghitung tingkat kepercayaan dari suatu hipotesis yang mungkin terjadi berdasarkan penggabungan evidence tersebut. Dalam implementasinya, teori Dempster-Shafer ini kemudian digunakan untuk penalaran dengan ketidakpastian. Ketidakpastian dalam penalaran terjadi disebabkan adanya penambahan fakta baru yang dapat mengubah konklusi yang sudah terbentuk.

Secara umum teori Dempster-Shafer ditulis dalam interval [Belief,Plausibility]

- Belief (Bel) adalah ukuran kekuatan evidence dalam mendukung suatu himpunan proposisi. Jika bernilai 0 maka mengindikasikan bahwa tidak ada evidence, dan jika bernilai 1 menunjukkan adanya kepastian.

- Plausibility $(P / s)$ dinotasikan sebagai : $\operatorname{Pls}(X)=1-\operatorname{Be} /(X)$

Jika yakin akan $X$, maka dapat dikatakan bahwa $\operatorname{Bel}(X)=1$, sedangkan nilai $\operatorname{Pls}(X)=0$ (Kusumadewi, 2003).

Sejumlah penelitian telah dilakukan menggunakan metode penalaran DempsterShafer, diantaranya Nahumpun (2014) membuat sistem pakar untuk diagnosa penyakit pada tanaman kelapa sawit, Maseleno \& Hasan (2013) untuk mendeteksi penyakit yang disebabkan oleh serangga, dan Wahyuni \& Prijodiprojo (2013) dalam mendeteksi tingkat resiko penyakit jantung koroner.

Pada tahun 2012 penulis melakukan penelitian mengenai sistem pakar, yaitu "Rancang Bangun Wireless Mobile System Pada Implementasi Diagnosa Penyakit Tanaman Padi Berbasis Certainty Factor". Metode penalaran yang digunakan penulis adalah certainty factor. Metode certainty factor relatif sederhana dalam perhitungan dibandingkan dengan Dempster-Shafer. Hanya saja metode Dempster-Shafer lebih baik dalam penentuan tingkat kepercayaan terhadap suatu keputusan karena mempertimbangkan semua variabel sehingga menghasilkan nilai perhitungan yang lebih variatif dan akurat (Setyarini dkk., 2014).

\section{METODE PENELITIAN}

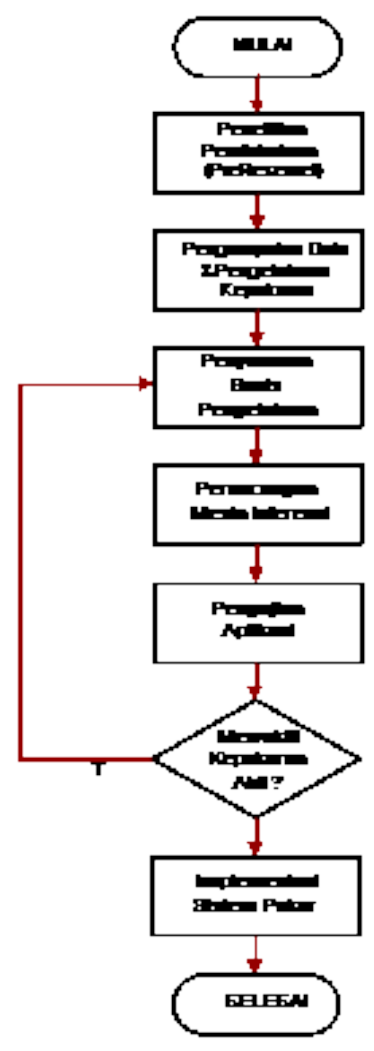

\section{Gambar 1. Diagram Alir Metodologi Penelitian}

Tahapan penelitian ditunjukkan dalam Gambar 1. Sistem pakar sendiri dirancang untuk aplikasi identifikasi hama dan penyakit tanaman jagung. 
Konsep dari sistem pakar adalah adopsi pengetahuan/kepakaran dari pakar ke dalam perangkat lunak. Untuk itu perlu dilakukan pengumpulan data dan pengetahuan yaitu jenis hama dan penyakit yang menyerang tanaman jagung dan gejala-gejala yang menyertai serangan.

Perancangan sistem pakar meliputi dua bagian, yaitu:

a. Penyusunan basis pengetahuan Data dan pengetahuan yang diperoleh disusun dalam bentuk tabel gejala, tabel penyakit, dan tabel pengetahuan. Basis pengetahuan tersebut kemudian disimpan dalam database sistem pakar.

b. Perancangan mesin inferensi

Perancangan mesin inferensi sistem pakar meliputi metode penelusuran dan metode penalaran.

Metode penelusuran yang digunakan dalam penelitian ini adalah Forward Chaining. Dalam pendekatan ini pelacakan dimulai dari gejala masukan dan selanjutnya mencoba menggambarkan kesimpulan. Penalaran dimulai dari fakta (bagian IF dari aturan IFTHEN) untuk menguji kebenaran hipotesis.

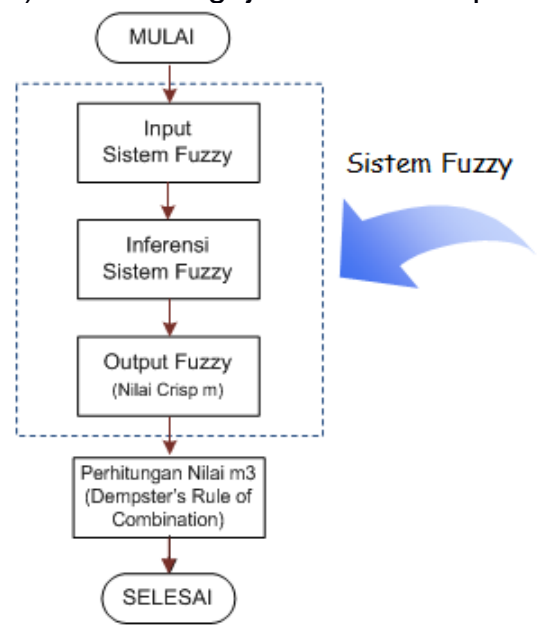

Gambar 2. Diagram Alir Metode Penalaran Menggunakan Fuzzy-Demspter Shafer

Metode penalaran yang digunakan adalah penalaran dengan ketidakpastian. Dalam penelitian ini digunakan metode ketidakpastian Dempster-Shafer.

Metode penalaran menggunakan Dempster-Shafer dimulai dari penentuan densitas $\mathrm{m} 1$ dan $\mathrm{m} 2$ yang merupakan nilai kepercayaan bahwa A dan B masing-masing merupakan gejala dari suatu hipotesa penyakit $X$ dan $Y$, dimana $X$ dan $Y$ adalah subset dari $\theta$. Dalam model hibrid Fuzzy-DempsterShafer, nilai $\mathrm{m} 1$ dan $\mathrm{m} 2$ ditentukan melalui sistem fuzzy seperti ditunjukkan dalam Gambar 2.
Output sistem fuzzy adalah nilai crisp m1 dan $\mathrm{m} 2$ yang akan digunakan untuk menghitung nilai $\mathrm{m} 3$ menggunakan aturan kombinasi Dempster. Nilai densitas $\mathrm{m} 3$ ini akan memberikan tingkat keyakinan pakar memberikan keputusan berdasarkan munculnya gejala A DAN B.

\section{Penyusunan Basis Pengetahuan}

Data pengetahuan meliputi jenis hama dan penyakit tanaman jagung serta gejala yang menyertai ditunjukkan dalam tabel 1 .

Tabel 1 Hama dan Penyakit Tanaman Jagung

\begin{tabular}{|l|l|}
\hline No. & \multicolumn{1}{|c|}{ Nama Hama dan Penyakit } \\
\hline $\mathrm{H} 1$ & Hama Lundi \\
\hline $\mathrm{H} 2$ & Hama Lalat Bibit \\
\hline $\mathrm{H} 3$ & Hama Ulat Grayak \\
\hline $\mathrm{H} 4$ & Hama Kumbang Landak \\
\hline $\mathrm{H} 5$ & Hama Kutu Daun \\
\hline $\mathrm{H} 6$ & Hama Penggerek Batang \\
\hline $\mathrm{H} 7$ & Hama Ulat Tongkol \\
\hline $\mathrm{H} 8$ & Hama Belalang \\
\hline $\mathrm{P} 1$ & Penyakit Bulai \\
\hline P2 & Penyakit Karat \\
\hline P3 & Penyakit Bercak Daun \\
\hline P4 & Penyakit Hawar Upih Daun \\
\hline P5 & Penyakit Busuk Tongkol \\
\hline P6 & Penyakit Kerdil Mosaik Jagung \\
\hline P7 & Penyakit Gosong Bengkak \\
\hline P8 & Penyakit Busuk Biji \\
\hline P9 & Penyakit Busuk Batang Diplodia \\
\hline
\end{tabular}

\section{Perancangan Sistem Fuzzy}

Perancangan sistem fuzzy digunakan untuk memperoleh nilai densitas $(\mathrm{m})$ meliputi penentuan input dan output, penentuan himpunan dan fungsi keanggotaan, penyusunan aturan (rules), serta penentuan metode inferensi. Dalam penelitian ini metode inferensi yang digunakan adalah metode Tsukamoto.

a. Perancangan Input dan Output Input sistem fuzzy merupakan nilai yang diinputkan oleh pakar untuk merepresentasikan tingkat kepercayaan terhadap suatu gejala yang menyerang. Gambar 3 memperlihatkan suatu sistem fuzzy dengan dua buah input yaitu tingkat kemunculan dan tingkat keunikan gejala, serta output berupa nilai densitas. 


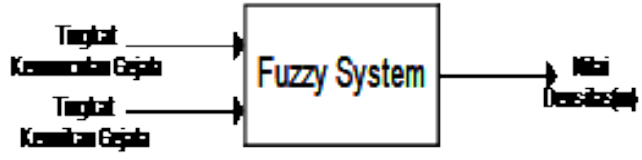

Gambar 3 Input dan Output Sistem Fuzzy

- Input 1:

Tingkat kemunculan gejala, menyatakan seberapa sering gejala muncul mengiringi suatu hama/penyakit yang menyerang. Dibagi menjadi himpunan Sangat Jarang, Kadang-Kadang, dan Sering Muncul.

- Input 2:

Tingkat keunikan gejala, menyatakan seberapa khas (unik) suatu gejala yang terdapat pada tanaman yang mengindikasikan suatu hama/ penyakit. Dibagi menjadi himpunan Rendah, Sedang, dan Tinggi.

- Output :

Nilai densitas $(m)$, terdiri dari himpunan Sangat Rendah, Rendah, Sedang, Tinggi, Sangat Tinggi

b. Perancangan Fungsi Keanggotaan

Untuk menyatakan derajat keanggotaan dari tiap anggota dalam himpunan fuzzy, digunakan fungsi keanggotaan (membership function). Fungsi keanggotaan dinyatakan dalam suatu kurva yang memetakan input ke dalam derajat keanggotaannya.

- Fungsi Keanggotaan Tingkat Kemunculan Gejala

$\bullet$

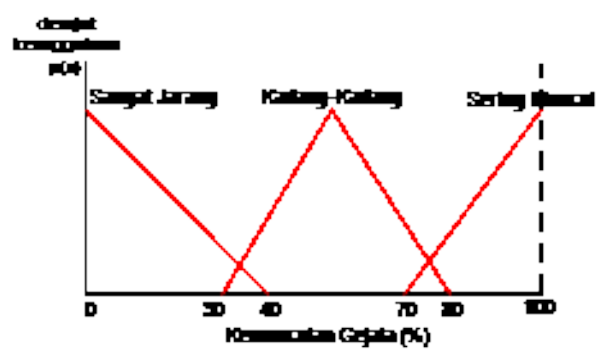

Gambar 4 Fungsi Keanggotaan Input 1

- Fungsi Keanggotaan Tingkat Keunikan Gejala

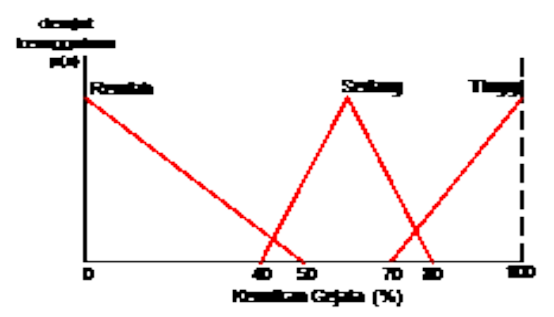

Gambar 5 Fungsi Keanggotaan Input 2
- Fungsi Keanggotaan Nilai Densitas (m)

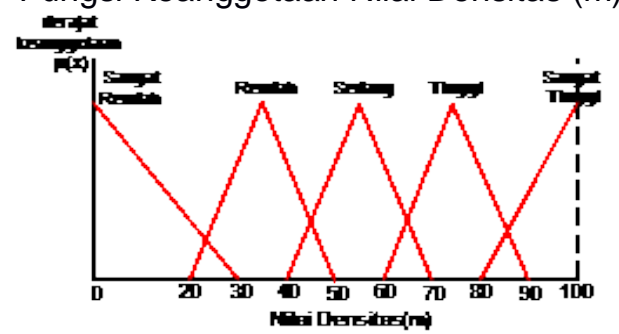

Gambar 6 Fungsi Keanggotaan Output

c. Perancangan Aturan Fuzzy

Aturan fuzzy yang disusun yaitu :

Aturan 1 JIKA Kemunculan Gejala adalah Sering Muncul dan Keunikan Gejala adalah Tinggi MAKA Nilai Densitas adalah Sangat Tinggi

Aturan 2 JIKA Kemunculan Gejala adalah Sering Muncul dan Keunikan Gejala adalah Sedang MAKA Nilai Densitas adalah Tinggi

Aturan 3 JIKA Kemunculan Gejala adalah Sering Muncul dan Keunikan Gejala adalah Rendah MAKA Nilai Densitas adalah Sedang

Aturan 4 JIKA Kemunculan Gejala adalah Kadang-Kadang dan Keunikan Gejala adalah Tinggi MAKA Nilai Densitas adalah Tinggi

Aturan 5 JIKA Kemunculan Gejala adalah Kadang-Kadang dan Keunikan Gejala adalah Sedang MAKA Nilai Densitas adalah Sedang

Aturan 6 JIKA Kemunculan Gejala adalah Kadang-Kadang dan Keunikan Gejala adalah Rendah MAKA Nilai Densitas adalah Rendah

Aturan 7 JIKA Kemunculan Gejala adalah Sangat Jarang dan Keunikan Gejala adalah Tinggi MAKA Nilai Densitas adalah Tinggi

Aturan 8 JIKA Kemunculan Gejala adalah Sangat Jarang dan Keunikan Gejala adalah Sedang MAKA Nilai Densitas adalah Rendah

Aturan 9 JIKA Kemunculan Gejala adalah Sangat Jarang dan Keunikan Gejala adalah Rendah MAKA Nilai Densitas adalah Sangat Rendah

\section{HASIL DAN PEMBAHASAN}

\section{Form Antarmuka}

a. Form Data Gejala

Untuk dapat menerapkan metode Dempster Shafer pada sistem pakar ini, diperlukan data gejala dan hama penyakit 
tanaman jagung. Karena itu diperlukan juga form pengelolaan data gejala dan data hama penyakit tanaman jagung seperti pada Gambar 7.

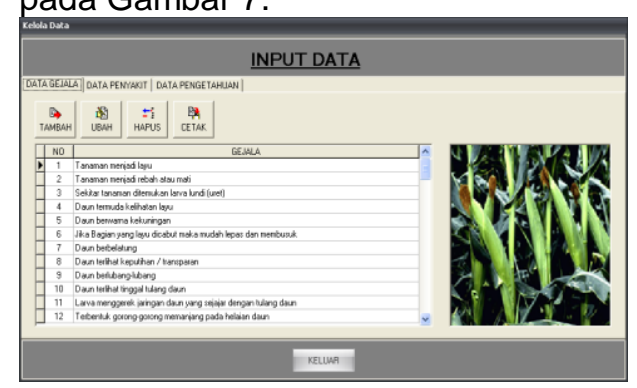

Gambar 7 Form Data Gejala

\section{b. Form Data Penyakit}

Form kelola penyakit digunakan untuk mengelola data yang ada pada tabel penyakit. Menu yang disediakan adalah tambah penyakit, ubah penyakit dan hapus penyakit. Gambar 8 menunjukkan form kelola penyakit.

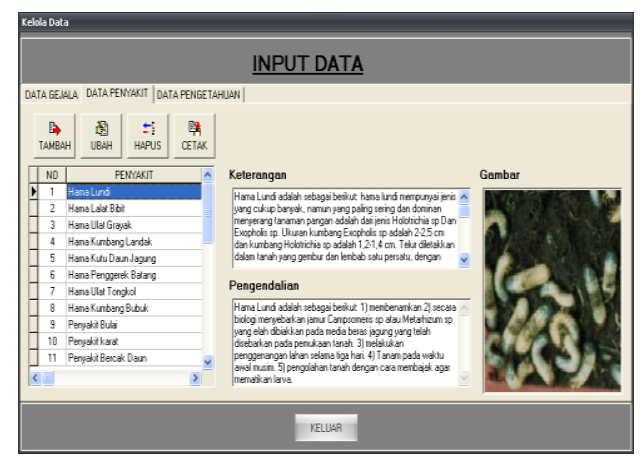

Gambar 8 Form Data Penyakit

\section{c. Form Data Pengetahuan}

Data pengetahuan berisi data yang diinputkan berupa gejala, penyakit dan nilai seringnya muncul gejala serta kekhasan/keunikan gejala. Form data pengetahuan merupakan form untuk mengelola data yang ada pada tabel pengetahuan. Menu yang disediakan adalah tambah, ubah dan hapus. Gambar 9 menunjukkan form data pengetahuan.

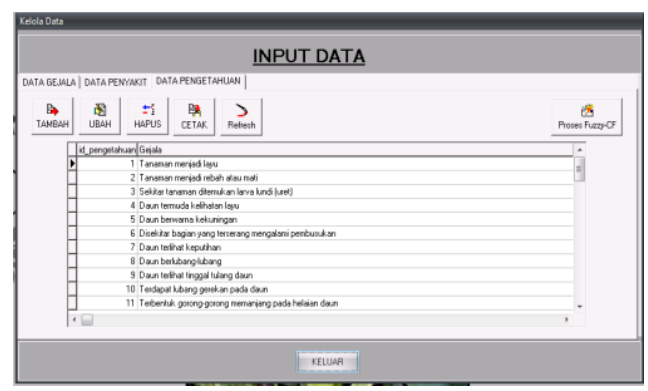

Gambar 9 Form Data Pengetahuan d. Form Identifikasi

Menu identifikasi adalah implementasi dari inferensi sistem pakar. Melalui form ini dapat dilakukan proses identifikasi seperti ditunjukkan dalam Gambar 9 Sistem akan memberikan informasi kemungkinan hama dan penyakit yang menyerang tanaman jagung berdasarkan gejala-gejala yang diinputkan pada Gambar 10.

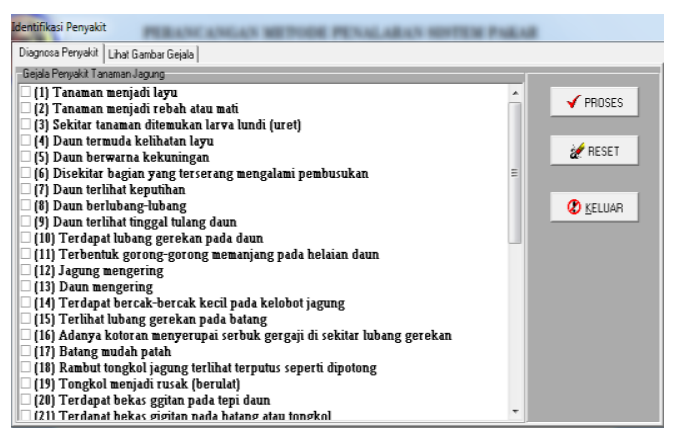

Gambar 9 Form Identifikasi

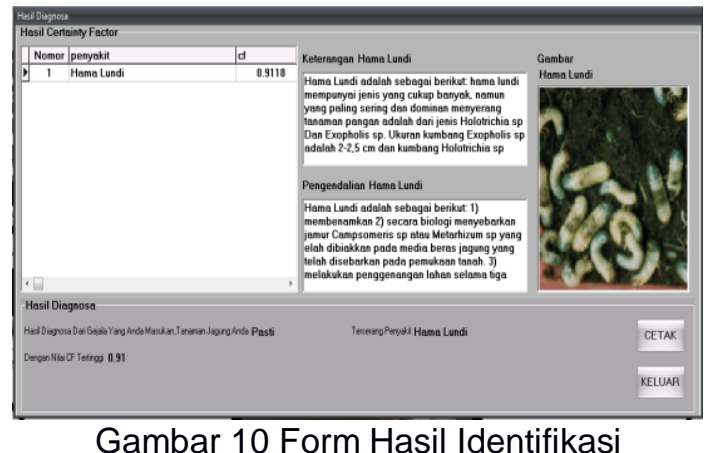

e. Form Informasi

Form ini berisi penjelasan secara umum mengenai hama dan penyakit tanaman jagung. Gambar 11 menunjukkan form mengenai deskripsi hama dan penyakit tanaman jagung.

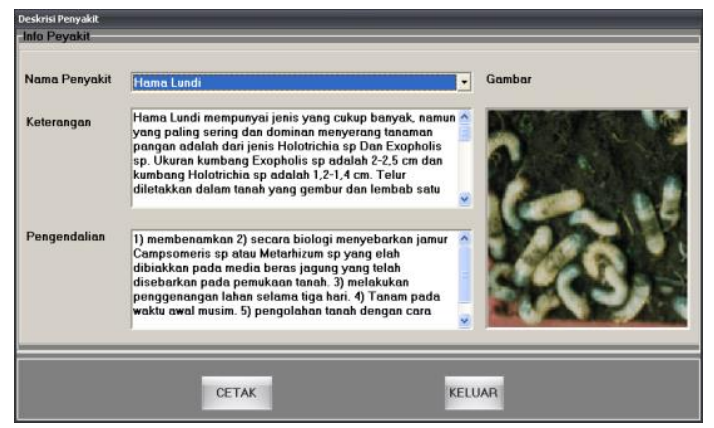

Gambar 11 Form Informasi

\section{f. Form Saran}

Form saran berfungsi sebagai media interaksi antara user dengan admin. Melalui form ini user dapat memberikan saran, masukan, kritik, pertanyaan mengenai sistem pakar yang dibangun 
seperti ditunjukkan dalam Gambar 12.

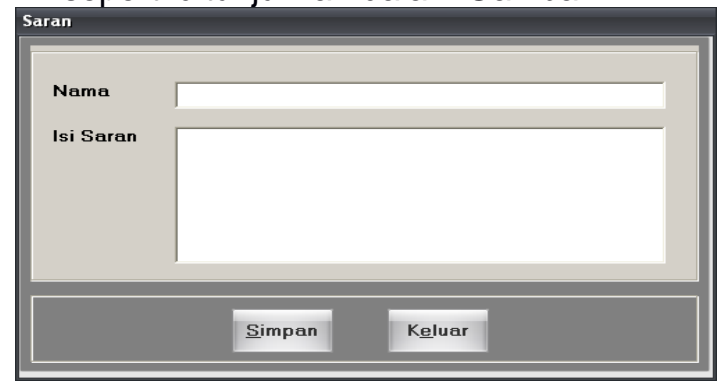

Gambar 12 Form Saran

\section{Pengujian Sistem Pakar}

Pengujian dimaksudkan untuk melihat kemampuan sistem pakar dalam mengidentifikasi hama dan penyakit tanaman jagung. Pengujian dilakukan dengan memberikan input gejala seperti pada Gambar 13, yaitu :

1) Daun mengering

2) Pada daun terdapat bercak bulat/oval berwarna coklat kemerahan

3) Terdapat serbuk berwarna kuning kecoklatan seperti karat

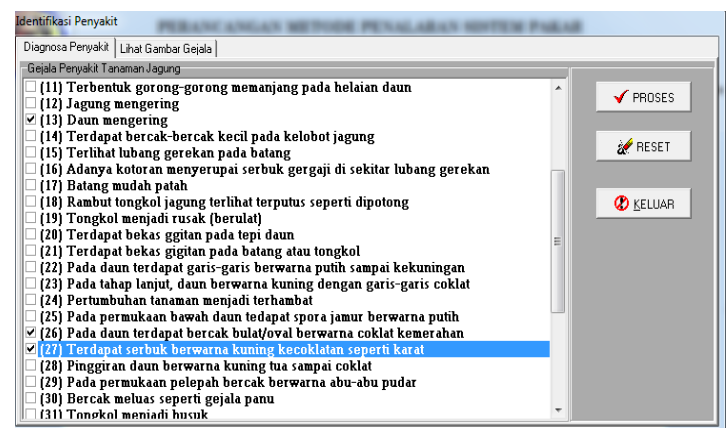

\section{Gambar 13. Proses Input Gejala Yang Menyerang}

Berdasarkan hasil perhitungan sistem pakar yang dibangun, diperoleh kesimpulan bahwa identifikasi hama atau penyakit yang menyerang tanaman jagung berdasarkan gejala yang diinputkan adalah penyakit karat karena memiliki nilai densitas yang paling kuat sebesar 0.933 (93.3\%) seperti ditunjukkan dalam Gambar 14.

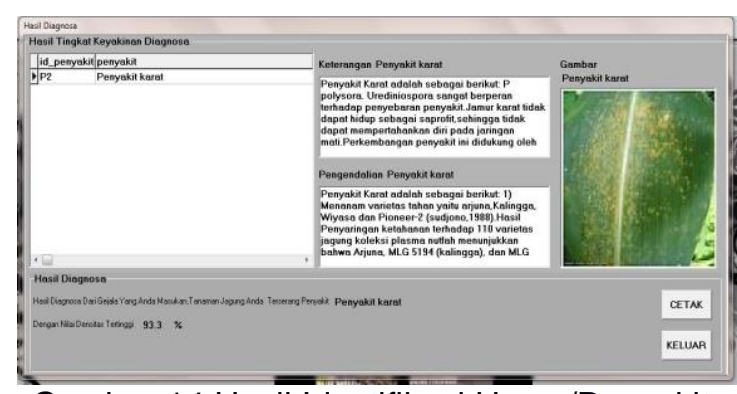

Gambar 14 Hasil Identifikasi Hama/Penyakit Yang Menyerang
Proses perhitungan menggunakan FuzzyDempster Shafer adalah sebagai berikut. Jika diketahui gejala yang menyerang tanaman jagung adalah :

1) G13 (daun mengering)

2) G26 (pada daun terdapat bercak bulat/oval berwarna coklat kemerahan)

Berdasarkan basis pengetahuan, G13 dan G26 merupakan gejala dari serangan hama penggerek batang ( $\mathrm{H} 6)$, penyakit karat (P2), penyakit bercak daun (P3), dan penyakit busuk batang diplodia (P9).

a. Nilai kepercayaan G13 sebagai gejala serangan H6, P2, P3, P9 adalah :

$\mathrm{m} 1\{H 6, P 2, P 3, P 9\}=0.65$

$$
\mathrm{m} 1\{\theta\}=1-0.75 \quad=0.35
$$

b. Nilai kepercayaan G26 sebagai gejala serangan $\mathrm{P} 2, \mathrm{P} 3$

$\mathrm{m} 2\{P 2, P 3\}=0.867$

$\mathrm{m} 2\{\theta\}=1-0.918=0.133$

Nilai densitas baru m3 dari munculnya kedua gejala tersebut dihitung dengan menggunakan aturan kombinasi Dempster seperti ditunjukkan dalam Tabel 2.

Tabel 2. Aturan Kombinasi Perhitungan m3

\begin{tabular}{|c|c|c|}
\hline & $\mathrm{m} 2\{P 2, P 3\}=0.867$ & $\mathrm{~m} 2\{\theta\}=0.133$ \\
\hline $\mathrm{m} 1\{H 6, P 2, P 3, P 9\}=0.65$ & $\{P 2, P 3\}=0.564$ & $\{H 6, P 2, P 3, P 9\}=0.0865$ \\
\hline $\mathrm{m} 1\{\theta\}=0.35$ & $\{P 2, P 3\}=0.303$ & $\theta=0.0466$ \\
\hline
\end{tabular}

- $\mathrm{m} 3\{P 2, P 3\}$

$=\frac{0.564+0.303}{1-0}$

$=0.867$

- $\mathrm{m} 3\{H 6, P 2, P 3, P 9\}$

$=\frac{0.0865}{1-0}$

$=0.0865$

- $\operatorname{m} 3\{\theta\}$

$$
\begin{aligned}
& =\frac{0.0466}{1-0} \\
& =0.0466
\end{aligned}
$$

Jika kemudian muncul gejala G27, maka nilai densitas (m4) yang terjadi akibat munculnya G27 harus dihitung kembali seperti ditunjukkan dalam Tabel 3.

1) G27 (Terdapat serbuk berwarna kuning kecoklatan seperti karat) 
Tabel 3 Aturan Kombinasi Perhitungan m4

\begin{tabular}{|c|c|c|}
\hline & $\mathrm{m} 4\{P 2\}=0.933$ & $\mathrm{~m} 4\{\theta\}=0.067$ \\
\hline $\mathrm{m} 3\{P 2, P 3\}=0.867$ & $\{P 2\}=0.8089$ & $\{P 2, P 3\}=0.0581$ \\
& & \\
\hline $\mathrm{m} 3\{H 6, P 2, P 3, P 9\}=0.0865$ & $\{P 2\}=0.0807$ & $\{H 6, P 2, P 3, P 9\}=0.0058$ \\
\hline $\mathrm{m} 3\{\theta\}=0.0466$ & $\{P 2\}=0.0435$ & $\theta=0.0031$ \\
\hline
\end{tabular}

- $\quad \mathrm{m} 5\{P 2\}$

$$
\begin{aligned}
& =\frac{0.8089+0.0807+0.0435}{1-0} \\
& =0.933
\end{aligned}
$$

- $\mathrm{m} 5\{P 2, P 3\}$

$$
\begin{aligned}
& =\frac{0.0581}{1-0} \\
& =0.0581
\end{aligned}
$$

- $\mathrm{m} 5\{H 6, P 2, P 3, P 9\}$

$=\frac{0.0058}{1-0}$

$$
=0.0058
$$

- $\operatorname{m5}\{\theta\}$

$$
\begin{aligned}
& =\frac{0.0031}{1-0} \\
& =0.0031
\end{aligned}
$$

Dari hasil perhitungan diperoleh nilai densitas terbesar adalah pada penyakit P2 yaitu 0.933 . Sehingga dapat disimpulkan bahwa identifikasi penyakit yang menyerang tanaman jagung berdasarkan gejala G13, G26, dan G27 adalah penyakit karat dengan nilai probabilitas densitas sebesar 0.933 .

\section{KESIMPULAN}

1) Sistem pakar menggunakan Dempster Shafer pada penelitian ini pada dasarnya merupakan upaya menentukan nilai densitas $\mathrm{m} 1$ dan $\mathrm{m} 2$ terhadap gejala 1 dan gejala 2 yang menyerang tanaman jagung

2) Nilai $m 1$ dan $m 2$ kemudian digunakan untuk menghitung nilai densitas baru (m3) menggunakan rumus kombinasi Dempster. Nilai $\mathrm{m} 3$ menyatakan tingkat kepercayaan terhadap suatu diagnosa hama/penyakit yang menyerang

3) Sistem pakar yang dirancang dapat memberikan hasil identifikasi berdasar pada gejala yang diinputkan. Penentuan jenis hama atau penyakit yang menyerang didasarkan pada proses pencarian nilai kepercayaan terhadap suatu diagnosa. Semakin besar nilai kepercayaan semakin besar pula potensi hama/penyakit yang menyerang, begitu pula sebaliknya.

\section{DAFTAR PUSTAKA}

[1] Gunawan,R.C., 2012, Rancang Bangun Wireless Mobile System Pada Implementasi Diagnosa Penyakit Tanaman Padi Berbasis Certainty Factor, Politeknik Negeri Banjarmasin

[2] Kusumadewi, S., 2003, Artificial Intelligence, Graha Ilmu, Yogyakarta

[3] Maseleno, A., and Hasan, M., 2013, The Dempster-Shafer Theory Algorithm and its Application to Insect Diseases Detection, International Journal of Advanced Science and Technology, Vol. 50

[4] Nahampun, M., (2014), Sistem Pakar Diagnosa Penyakit Pada Tanaman Kelapa Sawit Dengan Metode DempsterShafer, Pelita Informatika Budi Darma, Vol. VII, No. 1

[5] Setyarini, E., dkk., 2013, The Analysis of Comparison of Expert System of Diagnosing Dog Disease by Certainty Factor Method and Dempster-Shafer Method, IJCSI International Journal of Computer Science Issues, Vol. 10, Issue 1 , No 2

[6] Wahyuni, E. dan Prijodiprojo, W., 2013, Prototype Sistem Pakar untuk Mendeteksi Tingkat Resiko Penyakit Jantung Koroner dengan Metode Dempster-Shafer, IJCCS, Vol.7, No.2 